International Journal on Biological Sciences 12 (1), January-June 2021, pp 52-55

https://doi.org/10.53390/ijbs.v12.i1.6

ISSN No.: 0976-4518

\title{
STUDY ON THE LIPID CONTENT OF SELECTED FISHES (M.S.), INDIA
}

\author{
Arati Tidame $^{1}$, Shaikh Yasmeen ${ }^{2}$, Vikram Kakulte ${ }^{3}$, Jyoti Gangurde ${ }^{3}$ and Savita Tidame ${ }^{3 *}$ \\ ${ }^{1}$ Department of Zoology, LVH Panchavati College, Nashik (MS) \\ ${ }^{2}$ Department of Zoology, Dr. Rafiq Zakaria College for Women, Aurangabad MS) \\ ${ }^{3}$ Department of Zoology, K.T.H.M. College, Nashik (MS)
}

\section{Research Paper}

Received: 25.05.2021

Revised: 15.06.2021

Accepted: 22.06.2021

\section{ABSTRACT}

An estimation of lipid content in selected fishes namely rohu, mrigala, silver pomfret and pomfret was carried out during year 2018-2019. In the present study, authors found the amount of lipid content in rohu was $0.760 \mathrm{mg} /$, in mrigala 0.448 $\mathrm{mg} / \mathrm{g}$, in pomfret $0.753 \mathrm{mg} / \mathrm{g}$ and in silver pomfret $0.619 \mathrm{mg} / \mathrm{g}$. On the basis of result obtained, it can be concluded that, rohu and pomfret contain more amount of lipids as compared to mrigala and silver pomfret.

Keywords: Estimation, Lipid, Fish.

\section{INTRODUCTION}

Fishes are exclusively aquatic animals with streamlined body. They have gills for respiration and lateral line sense organs (Verma and Prakash, 2020). They have a very rich nutritive value, providing food and establishing the food security to human beings (Verma, 2007; Kumar et al., 2020). They have large amount of proteins and fats (Sujatha et al., 2013; Syed et al., 2020). They claimed that fishes are highly nutrient-dense food, containing high quality of minerals, vitamins and including vitamin A and $\mathrm{D}$, magnesium and phosphorus. Consuming whole fish can prove beneficial as it has a higher protein-fat ratio than meat from goat, lamb, buffalo, and chicken (Steffen, 2006). A significant percentage of the lipid in fish consists of long chain polyunsaturated fatty acids (PUFA) including eicosapentaenoic acid (EPA) and docosahexanoic acid (DHA). In fishes, PUFAs are found in a form that is liquid and flows freely through the bloodstream. It is different from other fats or oils (Morales et al., 2015). In humans, dietary intake of polyunsaturated fatty acids (PUFA) has been important for human nutritional, health, and disease prevention (Sujita et al., 2019). Omega-3 fatty acids commonly found in seafood have varied health benefits (Prakash and Verma, 2019, 2020). Reduction of myocardial infarction has been suggested by Bucher et al. (2002). As living organisms occupy the environment, lipids and their components play an integral role in their biochemical adaptations. Biochemical processes and life development rely heavily on these lipids. There is a range of functions that lipids play in cellular metabolism (Svetlana et al., 2013). Due to its widespread existence in the body, cholesterol is perhaps the well-publicized lipid in nature. Significant losses may occur during periods of high cholesterol levels in seasonal differences (Spinelli and Dassow, 1982; Prakash and Verma, 2018). Even though protein is an important source of energy in fishes but stress conditions causes rapid depletion of stored carbohydrate (Verma and Prakash, 2019; Prakash, 2020).

\section{MATERIALS AND METHODS}

In the present study Rohu, Mrigal, Pomfret and Silver pomfret were analyzed for their lipid content (Photo plate 2 ). For the estimation of lipid fishes were collected from local fish market of Pathardi phata, Nashik (M.S.) and brought them to laboratory one at a time. $1 \mathrm{~g}$ lateral body

*Corresponding author: savita.tidame@gmail.com 
tissue was taken and homogenized then homogenized sample was filtered through filter paper. The homogenized filtrate was used for further estimation (photo plate 1). Then lipid content of a particular fish was estimated by using standard procedure. Estimation of lipid was done by Vaniline reagent method; a standard method for lipid estimation (Barnes and Blackstock, 1973). $1 \mathrm{~g}$ tissue of fish (namely rohu, mrigala, silver pomfret and pomfret) was taken and homogenized in $10 \mathrm{ml}$ of 2:1 chloroform: methanol mixture (Photo plate 1). Homogenized sample was filter through Whatmann filter paper no.1. $1 \mathrm{ml}$ filtrate was taken in test tube and dried at room temperature for 1-2 days. After drying $1 \mathrm{ml}$ conc. $\mathrm{H}_{2} \mathrm{SO}_{4}$ was added. Then mixture was boiled for 7-10 min and cooled at room temperature. $0.2 \mathrm{ml}$ of supernatant solution was taken and $5 \mathrm{ml}$ of vaniline reagent added to it. At $530 \mathrm{~nm}$ the intensity of color was measured.
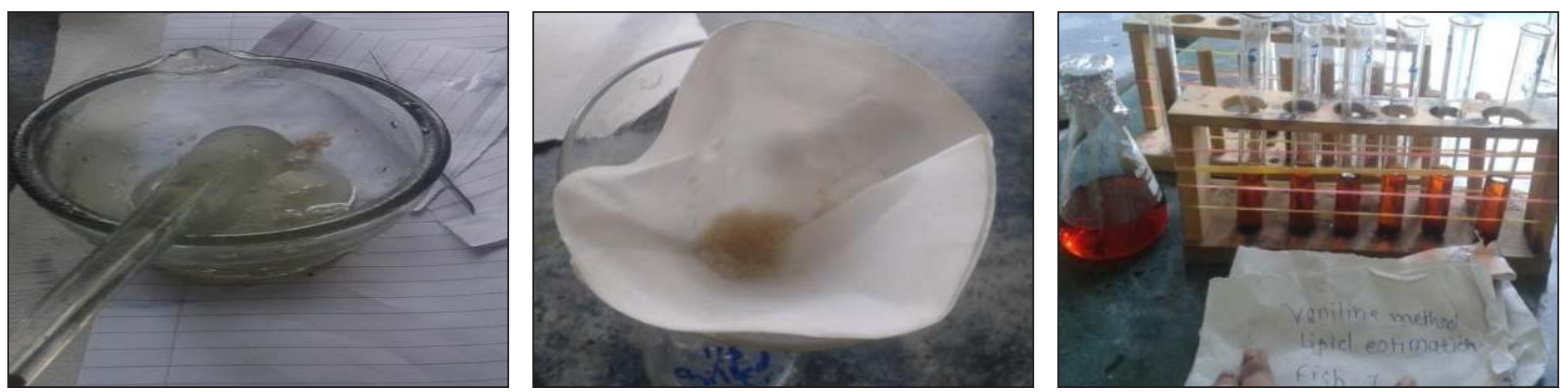

Photo plate 1: Images for Lipid estimation.
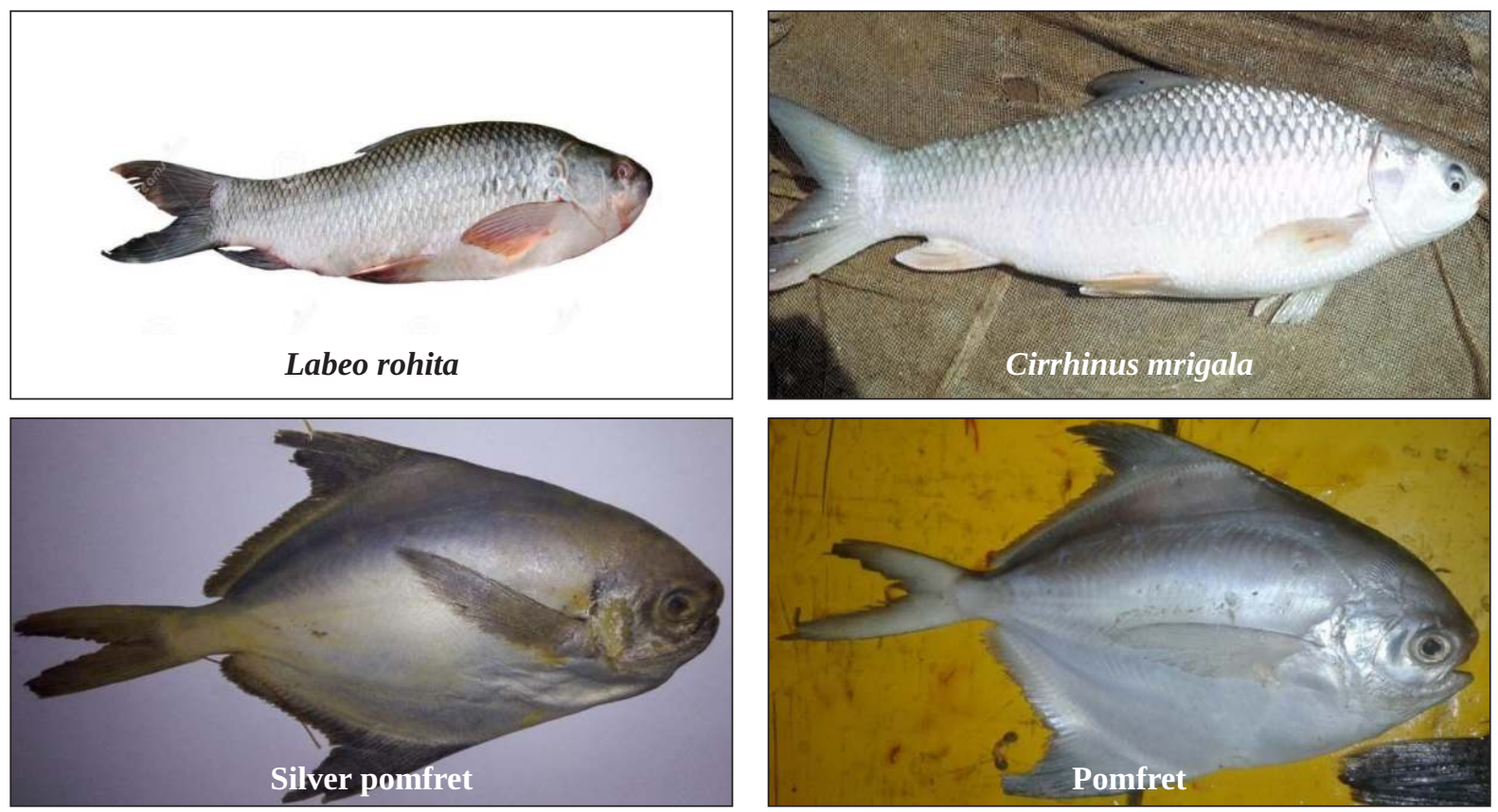

Photo plate 2. Photographs of the fishes under study.

\section{RESULTS AND DISCUSSION}

In the present study, lipid estimation was done from rohu, mrigala, pomfret, silver pomfret fishes. In rohu $0.760 \mathrm{mg} / \mathrm{g}$ lipid was estimated, in mrigala $0.448 \mathrm{mg} / \mathrm{g}$, in pomfret $0.753 \mathrm{mg} / \mathrm{g}$ and in silver pomfret 0.619 $\mathrm{mg} / \mathrm{g}$ as shown in table no. 2. Binukumari and Vasanthi
(2013) conducted their researches on Labeo rohita and estimated protein, lipid and carbohydrate under normal and experimental condition from different body tissues. They showed that the protein present in muscles of rohu was $2.89 \pm 0.052 \mathrm{mg} / \mathrm{g}$. Sivakami et al. (1994) reported that there was a marked decrease in 
protein, lipid and carbohydrate content in fresh water fish Mystus vittatus exposed to chromium. Saranya et al. (2014) reported the low value of lipid during January (2.772 $\mathrm{mg} / \mathrm{g}$ ) and high value in month of February and March in the fish Mrigala.

Fatty acids and lipids play a significant role in structuring of the membranes and directly impact several membrane-mediated processes, including nutrient absorption and transport. Species and habits of fish also affect the amount and type of lipids present in fish. Because of the strong association between high levels of cholesterol in the blood and diseases affecting the cardiovascular system, cholesterol is undoubtedly the most widely discussed lipid in nature. An important component of all cells, it contributes to permeability. It assists in the formation of bile acid and bile salts, 7dehydrocholestrol and vitamin D3, corticosteroid hormone, androgens, estrogens and progesterone. The lipid acts as an antagonist to phospholipids and is essential for the granulation of cell divisions (Sujatha etal., 2013).

Table 1: Concentration of standard lipid and their O.D.

\begin{tabular}{|l|c|}
\hline $\begin{array}{l}\text { Concentration of Std. } \\
\text { lipid (cholesterol) }\end{array}$ & O.D. \\
\hline 0 & 0 \\
\hline 0.2 & 1.17 \\
\hline 0.4 & 1.2 \\
\hline 0.6 & 1.27 \\
\hline
\end{tabular}

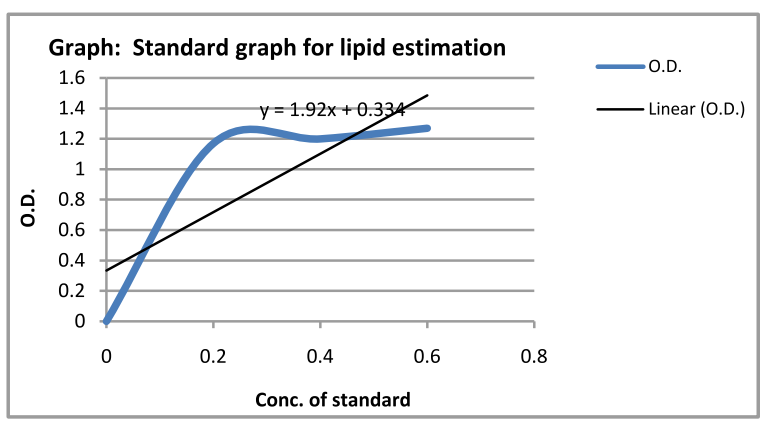

\section{Calculations: Lipid estimation}

$\mathrm{Y}=\mathrm{mx}+\mathrm{C}$

Where, $\mathrm{Y}=$ unknown O.D.

$\mathrm{M}=$ slope

$\mathrm{X}=$ concentration of known protein

$\mathrm{C}=$ intercept.
General formula used for Carbohydrate, Protein and lipid estimation is

$\mathrm{x}=\frac{(\mathrm{Y}-\mathrm{C})}{\mathrm{M}}$

Table 2: Lipid estimation of some fishes represented in terms of $\mathrm{mg} / \mathrm{g}$.

\begin{tabular}{|l|c|}
\hline Fishes studied & Lipid(mg/g) \\
\hline Silver pomfret & 0.619 \\
\hline Pomfret & 0.753 \\
\hline Rohu & 0.76 \\
\hline Mrigala & 0.448 \\
\hline
\end{tabular}

Rohu has highest source of lipid content, followed by pomfret and lowest in Mrigal. Silver pomfret contains low amount of lipid than rohu and pomfret and high amount of lipid content than Cirrhinus mrigala.

\section{ACKNOWLEDGEMENT}

The authors are thankful to Dr. V.B. Gaikwad, Principal, K.T.H.M. College, Nashik for permitting us to carry out this research work. We are thankful to the head Dr. V.R. Kakulte, for supporting and providing laboratory facilities. We are thankful to UGC and DBT who have sanctioned the funds for basic instrumentation facility in the Department of Zoology, KTHM College, Nashik (Maharashtra).

\section{REFERENCES}

1. Barnes, H. and Blackstock, J. (1973): Estimation of lipids in marine animals and tissues. Detailed investigation of sulphophos-phovanillin method for total lipids. J. Exp. Mar. Biol. Ecol. 12(1): 103-118.ttps://doi.org/10.1016/00220981(73)90040-3.

2. Binukumari, S. and Vasanthi, J. (2013): The Toxic effect of Dimethoate 30\% EC on the protein metabolism of the fresh water fish Labeo rohita. International Journal of Current Microbiology and Applied Sciences, 2(12):79-82.

3. Bucher, H.C., Hengstler, P. Schindler, C., and Meier, G. (2002): N-3 polyunsaturated fatty acids in coronary heart disease: a meta-analysis of randomized controlled trial. The American Journal of Medicine. 112: 298-304.

4. Kumar A., Bajpeyee A. K. and Yadav C.B. (2020). Effects of Dietary vitamin-C on 
Biochemical and Morphometric parameters of Labeo rohita. International Journal of Biological Innovations. 2 (2): 174-177. ttps://doi.org/ 10.46505/IJBI.2020.2214.

5. Morales, M. Hogaldo, F. and Sevenich, R. (2015). Fatty acids profile in canned tuna and sardine after retort sterilization and high-pressure thermal sterilization treatment. Journal of Flood and Nutrition Research, 54(2): 171-178.

6. Prakash, S. (2020): Toxic Effect of Chlorpyrifos pesticides on the behavior and serum biochemistry of Heteropneustes fossilis (Bloch). International Journal of Agricultural Biosciences. 11(1): 22-27.

7. Prakash, S. and Verma, A. K. (2018): Effect of synthetic detergent on Biochemical constitutions of Freshwater major carp, Labeo rohita. International Journal on Agricultural Sciences. 9(1):56-59.

8. Prakash, S. and Verma, A. K. (2019): Acute toxicity and behavioural responses in Arsenic exposed Mystus vittatus (Bloch). International Journal on Agricultural Sciences, 10 (1): 1-3.

9. Prakash, S. and Verma, A. K. (2020): Effect of Organophosphorus pesticides on Biomolecules of fresh water fish, Heteropneustes fossilis (Bloch). Indian Journal of Biology. 7(2):65-69.

10. Saranya S, Saravanan K, Durairaj K, Durga B. (2014): Comparative variation of Biochemical Parameters in cultural and Natural fishes. International Journal of Pharmaceuticals and Biological Archives: 5(2):104-107.

11. Sivakami R., Premkishore G. and Chandran M.R. (1994). Effect of chromium on the metabolism in selected tissue in the freshwater catfish Mystus vittatus. Env Eco.12(2): 259-266

12. Spinelli, J. and Dassow, J. A. (1982). Chemistry and Biochemistry of Marine Food Products, AVI Publishing Company, Westport, Connecticut. Westport.
13. Steffen, W. (2006). Freshwater Fish-Wholesome foodstuffs. Bulgarian Journal of Agricultural Science, 12: 320-328.

14. Sujatha, K. AnithaJoice, A. and Senthilkumar, P. (2013): Total protein and lipid content in Edible tissues of fishes from Kashimodu fish landing centre, Chennai, Tamilnadu. European Journal of Experimental Biology, 3(5): 252-257.

15. Sujita B., Sharma A. and Karn R. (2019). Significance of Nutritional value of fish for Human health; Malaysian Journal of Halal Research Journal, 2 (2):32-34.10.2478/mjhr2019-0012

16. Svetlana, A.M., Zinaida, A.N., Stig Falk Peteren, Pauli, O.R., Tatiana, R.R., Svetalana, N.P., Nina, N.N. (2013). Lipid Status of the Two High Latitude Fish Species, Leptoclinus maculatus and Lumpenus fabricii. International Journal of Molecular Science, 14 (4): 70487060.10.3390/ijms14047048.

17. Syed S.R.A, Abdhakir E. S., Muthukkaruppan R., Sheriff M. A. and Ambasankar K. (2020). Nutrient Composition of Some Marine Edible Fish Species from Kasimedu Fish Landing Centre, Chennai (TN), India. International Journal of Biological Innovations. 2 (2): 165-173. https://doi.org/10.46505/IJBI.2020.2213.

18. Verma, A. K. and Prakash, S. (2019): Impact of Arsenic on carbohydrate metabolism of a fresh water catfish, Mystus vittatus. International Journal on Biological Sciences. 10(1): 1719.

19. Verma A.K. and Prakash S. (2020). Status of Animal Phyla in different Kingdom Systems of Biological Classification. International Journal of Biological Innovations. 2 (2): 149-154. https://doi.org/ 10.46505/IJBI.2020.221. 